\title{
Culture as Indonesia Educational Base to Form Competitiveness and National Character
}

\author{
I Ketut Sudarsana ${ }^{1}$, Fatkul Anam ${ }^{2}$, Dian Rianita ${ }^{3}$, Rinandita Wikansari ${ }^{4}$, Maria Magdalena \\ Namok Nahak ${ }^{5}$, Rianti Setyawasih ${ }^{6}$, I Wayan Wirta ${ }^{7}$, Erwinsyah Satria ${ }^{8}$, I Wayan Sukabawa \\ \{iliketutsudarsana@uhnsugriwa.ac.id\} \\ ${ }^{1,7,9}$ Universitas Hindu Negeri I Gusti Bagus Sugriwa Denpasar, Bali, Indonesia, ${ }^{2}$ Universitas Wijaya \\ Kusuma, Surabaya, Indonesia, ${ }^{3}$ Faculty of Administration - Universitas Lancang Kuning, Pekanbaru, \\ Indonesia, ${ }^{4}$ Politeknik APP Jakarta, Indonesia, ${ }^{5}$ Universitas Timor, Nusa Tenggara Timur, Indonesia, \\ ${ }^{6}$ Faculty of Economics; Management Program; Universitas Islam 45 Bekasi, Bekasi, Indonesia, \\ ${ }^{8}$ Elementary School Teacher Education Program, Faculty of Teacher Training and Education, \\ Universitas Bung Hatta, Padang, Indonesia
}

\begin{abstract}
Human is a living creature who is given various potency by God. The least potential is human has faculty. However, this faculty should be used as best as they can, it is provision to live their life. To maximize all the potency which human has, there should be some thing which can direct and guide them, in order to run on the right track. Considering that how big and how precious it is, so human has to have a good educational base from the beginning of their school period. In other side, human has also ability and different the thoughts with other living creatures. Beside that, education is an aimed effort and planned to help the developement of human potency and their ability.
\end{abstract}

Keywords: Culture; Indonesia Educational Base; Competitiveness; National Character

\section{Introduction}

Based on sociology, education is a cultural heritage from one generation to generation, in order to have sustainable life for people and people's identity still maintained. Culture is the closest part of human life and almost every people activity always has cultural element. Entering the $21^{\text {st }}$ century and welcoming the third millenium, of course there will be many changes in society as the impact from globalization era. The fact is people undergoing cultural transformation onward fastly, and show disintegrative phenomenon in many life principle and become problems, education is one of the problems. Culture has big impact on education, it causes of paradigm friction of education, it is change life style such as the way we communicate, the way we think, and how to achieve prosperity. By knowing how great this world developement, in hopes that education can have good and wise respons to that great development [1].

Education has many definitions and it is different one with others. It depends to each point of view. According to Drikarya, educatio is an effort to make human to be human. While Crow and Corw have view that education is a process which is contain of many activities and good for people's social life, education helps to sustain tradition, culture, as well as social institution from generation to generation. And Ki Hajar Dewantara said that education means power to grow workmanship, intelectual, and physical. According to constitution law Number 
20 year 2003 chapter 1 verse 1 , it is said that education is an aimed effort and planned to achive learning environment ad learning process in order to make pupils actively develope their potency. Personality, intelegent, good manner, and skillful which is needed by their selves or people. Education is main fondation which makes strenghthen the education, in one of to make education has the best quality.

According to some view about the definition of education above, in fact, education is one of processess to educate, it is a process to influence the pupils in order to be able to adapt as best as they can, and it makes changes in his life, which is can be done in guiding them, teaching them, and traiming [2].

Culture is all thought system, value, moral, and belief that created by society. Thought system, value, moral, and belief are born from people interaction among one with others, as well as with the environment. Thought system, value, moral, norms and belief it is used in human life and produce social system, economy system, belief system, knowledge system, technology, arts, and so on. Human as social being become inventor for thought system, value, moral, norms, and belief; besides in society interaction and environment, people ruled by thought system, value, moral, norms, and belief that come from themshelves. When people's life keep developing, the true dovelopment is social system, economy system, belief, knowledge, technology, and also art. Education is aimed effort to develope potency of pupils so they have thought system, value, moral, belief which is inhereted their society dan develope the heritage to nowadays and future life [3].

In one simple society that has formed and known the education system in a form of local wisdom. In modern society which has been diferentiated known as an institute form, it is called the process of the occurance of cultural transmission and its developments. Indonesia is consist of tribes, cultures, races, and religion (multicultural) has various locam wisdom. Such as Bali with its local wisdom, it is has world view as Tri Hita Karana, and in social view is Manyama Braya, Salunglung Sabayantaka and in organization form is subak sekehe mabanjar, and so on.

\section{Method}

This research approach is the study of literature, where researchers not only collect, read and record literature / books that are understood by many people, but far from that researchers pay attention to the steps in researching literature, must pay attention to research methods in order to collect data, read and processing library materials and equipment that must be prepared in the study, their usefulness makes it easier for researchers to obtain data.

\section{Result and Discussion}

The development of national culture is only able to be done in an educatinal process which doesn't let the pupils away from social environment, social culture, and national culture, social environment and national culture is Pancasila; so culture in national education has to be based on Pancasila values (Pancasila: Five Principle of Indonesia) in pupils minds through heart, brain, and physich education. Education is also effort of people and nation on preparing the young generations for sustaining society life and nation to have a better future. The sustaining is signed of cultural inheretance and or character that has been owned by society and the 
nation it self. There for, education is a process of cultural inheretance and national character inheretance for young generations and also developing process of cultural and national character to increasing society life quality and nation in future [4] [5].

The basic of culture in the process of education of pupils actively has purpose to develope their own potencies, doing internalization process, and appreciation of values that can be their personalities whe they have interaction with the society, developing of more prosperous for social life, and also developing national society which has dignity.

According to the thoughts, the developement o base culture in education is very strategic for the sustaining and supremacy of the nation in future. The developement should be done through the right planning, and the suitable approaching, and the right learning method, also efective learning. It has to be appropiate with the character of value, education, culture, and national character is a collective of school effort; because of that, it has to be done collectively by all teachers and school chairman through all subjects and become one of unseparated from school culture [6].

Education is one of is an aware effort to develope the pupils potency optimally. This aware effort can be taken awat from the enviroment where the pupils are, especially from their cultural environment because the pupils's life cannot be apart from their environment and behave according to their culture rules. Education which is not based on those principle will cause the pupils away from their cultural roots. When this occurs, they will never know the culture with a good way, so the pupils will be a "stranger" in their cultural environment. Beside become stranger, the worst thing from all is he or she become some one who doesn't like he or she own culture.

Culture which causes the pupils grow and develope, it is started from culture in nearest environment (village, neighborhood association, citizen association, and wide range of village government) (kampung, RT, RW, desa) developes to the wider environment, it is national culture and universal culture which is embraced by some one who doesn't know he or she national culture well and he or she doesn't kow him self or her self as a part of national culture. In this situation, he or she is really susceptible to outside culture and tends to accept the outside culture without valueing process. This tend happens because he or she doesn't have norms and national culture value which can be usded as the basic to consider some thing (valueing) [7] [8].

The stronger some one has basic valueing, the stronger he or she tends to grow and develope to be a good citizen. In the point of culmination, norms and culture value in macro level collectively will be norms and national culture value. Thus, pupils will be Indonesian citizen who have perception, the way of thinking, the way of behaving, and the way of solving problems based on norms and his or her Indonesian character [9].

This appropiates with the main function of education which is delivered on law contitution of Sisdiknas "Developing ability and form chacarter, as well as national civilization with honorable value to make the nation intellegent." There for, the basic rules which rules national education (UUD 1945 and UU Sisdiknas) have given the strong basic to develope all the potency from a person who is a meber of society and natinal.

Education is a enculturation process, it has function to heritate values and past time achievement to future generation. These values and achievements is nation pride and makes the nation known by other nations. Beside inheriting values and achievemenet, education also has function to develope cultural values and past time achievement to be national cultural values which appropiates with nowadays life and future life. And also developes new achievement which can be new character and new culture for the nations. There for, the basic of culture in national education is the main of an educational process. 


\section{Conclusion}

The process of values developemnet which become the base of culture requires a sustaining process, it is done through many subjects which is in curriculum (Nationality Subject, History, Geography, Economy, Sociology, Antropology, bahasa Indonesia, Social science, Natural science, mathematic, Religion, Physical Excercise, arts, and skills). On developing national education, the awareness of who he or she is and the awareness of which he or she nation is, they are the most important parts.

This awareness will only be able to build in a good way through the history which gives enlightment and explanation regarding who is he or she nation in the past which produces him self or her self and he or she nation now. Besides, education has to be able to build awareness, knowledge, perception, and values about living environment and the place of his or her nation stay (geography), values which lives in society (antropology), and the valid and developing social system (sociology), state administration system, government, and politic (state administration/politic/nationality), bahasa Indonesia with the way of thinking, economy lide, knowledge, technology, and arts. It means education needs an effort on curriculum breakthrough, such as developing cultural values (local wisdom) which is become a basic for national education. With this curriculum breakthrough, cultural value which is developed in pupils's minds will be very strong and it will have a real impact in life, society, nation, and more over, it will have the big impact in the world wide.

\section{References}

[1] M. Pidarta, Landasan Kependidikan Stimulus Ilmu Pendidikan Bercorak Indonesia. Jakarta: Rineka Cipta, 2013.

[2] A. N. Ruswandi, Uus Hermawan Heris, Landasan Pendidikan. Bandung: CV. Insan Mandiri, 2008.

[3] P. Suweka, Sugiharta, Oka and I. K. Sudarsana, "Hypnotic Learning Characteristics On Sisya Brahmakunta Community In Denpasar," Vidyottama Sanatana Int. J. Hindu Sci. Relig. Stud., vol. 1, no. 2, pp. 132-145, 2017.

[4] Kurnisar, "Pancasila Sumber Dari Segala Sumber Hukum,” J. Ilm. Ilmu Sos., 2012.

[5] Ihsan, "Kecendrungan Global Dalam Proses Pembelajaran Pendidikan Pancasila dan Kewarganegaraan di Sekolah," Pancasila dan Kewarganegaraan, 2017.

[6] H. A. R. Tilaar, Pedagogik Teoritis Untuk Indonesia. Jakarta: PT. Kompas Media Nusantara, 2015.

[7] S. Soeprapto, "Implementasi Pancasila Dalam Kehidupan Ber Masyarakat Berbangsa Dan Bernegara," J. Ketahanan Nas., 2016.

[8] B. Manullang, "Grand Desain Pendidikan Karakter Generasi Emas 2045," J. (Pendidikan Karakter), 2013.

[9] R. Nugroho, Pendidikan Indonesia : Harapan, Visi, dan Strategi. Yogyakarta: Pustaka Pelajar, 2008 . 